\title{
Celebrating 50 years of Butterfly Conservation: a special issue on the ecology and conservation of butterflies and moths
}

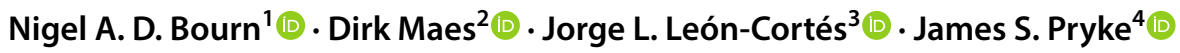

Published online: 6 May 2019

(c) Springer Nature Switzerland AG 2019

Butterfly Conservation (UK)'s 8th International Symposium was held at the University of Southampton between the 6th and 8th April 2018, Butterfly Conservations 50th anniversary year. Over 200 delegates listened to 78 talks and read 46 posters from 24 countries across the world.

This was Butterfly Conservation's second symposium entitled "The Ecology and Conservation of Butterflies and Moths", the title being deliberately broad to encourage as many scientists and conservation practitioners from a diverse range of disciplines from around the world to gather and share their research and conservation action with a global community of Lepidopterists (Dover et al. 2015). The 18 papers published in this special issue of the Journal of Insect Conservation reflect the broad theme of the symposium.

Much of this special volume is concerned about the status, ecology and conservation actions needed for rare and threatened species and their habitats at a range of scales (Ellis et al. 2019; Maes et al. 2019a; Middlebrook et al. 2019; Nowicki et al. 2019; Vrabec et al. 2019). While concerns

Dirk Maes

dirk.maes@inbo.be

Nigel A. D. Bourn

nbourn@butterfly-conservation.org

Jorge L. León-Cortés

jleon@ecosur.mx

James S. Pryke

jpryke@sun.ac.za

1 Butterfly Conservation, Manor Yard, East Lulworth, Wareham, Dorset BH20 5QP, UK

2 Species Diversity Group, Research Institute for Nature and Forest (INBO), Herman Teirlinckgebouw, Havenlaan 88 bus 73, 1000 Brussels, Belgium

3 Departamento de Conservación de la Biodiversidad, El Colegio de la Frontera Sur, Carr. Panamericana y Periférico Sur S/N, 29290 San Cristóbal de las Casas, Chiapas, Mexico

4 Department of Conservation Ecology and Entomology, Stellenbosch University, Private Bag X1, Matieland 7602, Western Cape, South Africa about widespread species and how to conserve them are also reflected (Dennis et al. 2019; Geest et al. 2019). Detailed, autecological studies have always been and continue to be the backbone of butterfly conservation and several authors have added to this body of work (Cini et al. 2019; Marschalek et al. 2019). In an increasingly globalised world, the risks from non-native pests and pathogens is also increasing, which is the subject of a paper from America from Gezon et al. (2019) and Paradiso et al. (2019) from Europe helping to demonstrate the global nature of this threat to our wildlife.

Research on butterfly populations, particularly on metapopulation structure and habitat quality has led to the development and delivery of landscape scale conservation and urban butterfly ecology initiatives. This broad tradition is maintained in this volume with several papers in this field (Münsch et al. 2019; Sielezniew et al. 2019; Topp and Loos 2019; Viljur et al. 2019; León-Cortés et al. 2019).

Setting conservation priorities is crucial if resources are to be spent wisely and two papers demonstrate both the usefulness of IUCN Red Lists and how to use and improve them for short-lived invertebrates (Fox et al. 2019; Maes et al. 2019b).

We would like to thank all the authors that submitted such an interesting and broad array of papers. At a time of Insectageddon (Thomas et al. 2019), robust data and rigorous analyses have never been more important for the conservation of butterflies, moths and their habitats.

\section{References}

Cini A et al (2019) Host plant selection and differential survival on two Aristolochia L. species in an insular population of Zerynthia cassandra. J Insect Conserv 23(2):239-246. https://doi.org/10.1007/ s10841-018-0105-5

Dennis EB, Brereton TM, Morgan BJT, Fox R, Shortall CR, Prescott T, Foster S (2019) Trends and indicators for quantifying moth abundance and occupancy in Scotland. J Insect Conserv 23(2):369380. https://doi.org/10.1007/s10841-019-00135-z 
Dover JW, Bourn NAD, Lewis OT, Shreeve TG (2015) The ecology and conservation of butterflies and moths. J Insect Conserv 19:183-184. https://doi.org/10.1007/s10841-015-9770-9

Ellis S et al (2019) Are habitat changes driving the decline of the UK's most threatened butterfly: the High Brown Fritillary Argynnis adippe (Lepidoptera: Nymphalidae)? J Insect Conserv 23(2):351-367. https://doi.org/10.1007/s10841-019-00134-0

Fox R, Harrower CA, Bell JR, Shortall CR, Middlebrook I, Wilson RJ (2019) Insect population trends and the IUCN Red List process. J Insect Conserv 23(2):269-278. https://doi.org/10.1007/s1084 1-018-0117-1

Geest EA, LaReesa Wolfenbarger L, McCarty JP (2019) Recruitment, survival, and parasitism of monarch butterflies (Danaus plexippus) in milkweed gardens and conservation areas. J Insect Conserv 23(2):211-224. https://doi.org/10.1007/s10841-018-0102-8

Gezon Z, Braatz E, Duxbury C, Savage A, Daniels J (2019) Longterm trends in Persea palustris and Lauraceae-dependent butterfly species in central Florida before and after the introduction of laurel wilt disease. J Insect Conserv 23(2):341-350. https://doi. org/10.1007/s10841-019-00129-x

León-Cortés JL, Caballero U, Miss-Barrera ID, Girón-Intzin M (2019) Preserving butterfly diversity in an ever-expanding urban landscape? A case study in the highlands of Chiapas, Mexico. J Insect Conserv 23(2):405-418. https://doi.org/10.1007/s1084 1-019-00149-7

Maes D et al (2019a) The potential of species distribution modelling for reintroduction projects: the case study of the Chequered Skipper in England. J Insect Conserv 23(2):419-431. https://doi. org/10.1007/s10841-019-00154-w

Maes D et al (2019b) Integrating national Red Lists for prioritising conservation actions for European butterflies. J Insect Conserv 23(2):301-330. https://doi.org/10.1007/s10841-019-00127-z

Marschalek DA, Faulkner DK, Deutschman DH (2019) Ecology of the threatened Harbison's dun skipper (Euphyes vestris harbisoni) for conservation efforts within a habitat conservation plan. J Insect Conserv 23(2):331-339. https://doi.org/10.1007/s1084 1-019-00128-y

Middlebrook I, Hardy PB, Botham MS, Dennis RLH (2019) The importance of unique populations for conservation: the case of the great orme's head grayling butterfly Hipparchia semele (Linnaeus, 1758) (Lepidoptera: Satyrinae). J Insect Conserv 23(2):381-391. https://doi.org/10.1007/s10841-019-00137-x
Münsch T, Helbing F, Fartmann T (2019) Habitat quality determines patch occupancy of two specialist Lepidoptera species in wellconnected grasslands. J Insect Conserv 23(2):247-258. https:// doi.org/10.1007/s10841-018-0109-1

Nowicki P, Deoniziak K, Dziekańska I, Kostro-Ambroziak A, Plazio E, Rutkowski R, Sielezniew M (2019) What keeps 'living dead' alive: demography of a small and isolated population of $\mathrm{Macu}$ linea (= Phengaris) alcon. J Insect Conserv 23(2):201-210. https ://doi.org/10.1007/s10841-018-0078-4

Paradiso F et al (2019) From Africa to the Alps: risk assessment on an invasion by Cacyreus marshalli (Butler, 1898). J Insect Conserv 23(2):279-288. https://doi.org/10.1007/s10841-018-00124-8

Sielezniew M, Deoniziak K, Dziekańska I, Nowicki P (2019) Dispersal in a metapopulation of the critically endangered Danube Clouded Yellow butterfly Colias myrmidone: implications for conservation. J Insect Conserv 23(2):291-300. https://doi.org/10.1007/ s10841-019-00126-0

Thomas CD, Jones TH, Hartley SE (2019) "Insectageddon": a call for more robust data and rigorous analyses. Global Change Biol. https ://doi.org/10.1111/gcb.14608

Topp EN, Loos J (2019) Local and landscape level variables influence butterfly diversity in critically endangered South African renosterveld. J Insect Conserv 23(2):225-237. https://doi.org/10.1007/ s10841-018-0104-6

Viljur M-L, Relve A, Gimbutas M, Kaasik A, Teder T (2019) Dispersal of open-habitat butterflies in managed forest landscapes: are colonisers special? J Insect Conserv 23(2):259-267. https://doi. org/10.1007/s10841-018-0112-6

Vrabec V, Bubová T, Kulma M, Krása A, Nowicki P (2019) How Euphydryas maturna survived extinction in the Czech Republic: status of a relic population after intensive conservation management. J Insect Conserv 23(2):393-403. https://doi.org/10.1007/ s10841-019-00145-x

Publisher's Note Springer Nature remains neutral with regard to jurisdictional claims in published maps and institutional affiliations. 